\title{
Biosorption of lead (II) from water using heartwood charcoal of Areca catechu: equilibrium and kinetics studies
}

\author{
Nabanita Haloi • H. P. Sarma $\cdot$ P. Chakravarty
}

Received: 31 August 2011/Accepted: 30 May 2013/Published online: 14 June 2013

(C) The Author(s) 2013. This article is published with open access at Springerlink.com

\begin{abstract}
Present study was conducted to investigate the removal of $\mathrm{Pb}$ (II) from water by using heartwood charcoal of Areca catechu (HCAC). Batch experiments were conducted to determine the adsorption properties at different contact times $(5-30 \mathrm{~min})$, concentrations $(0.1-10 \mathrm{mg} / \mathrm{L})$, amounts of adsorbents $(0.1-0.6 \mathrm{~g})$, and in a range of $\mathrm{pH}$ 2-7. Most favorable biosorption condition was found at $\mathrm{pH}$ 5.0, $0.5 \mathrm{~g}$ biomass dosage and at $25 \mathrm{~min}$ equilibrium time. The experimental results were fitted to the Langmuir and Freundlich isotherm models; the Freundlich isotherm was found to well represent the measured sorption data implying HCAC has heterogeneous surface. Lagergren first-order and pseudo-second-order kinetic model were used to analyze the biosorption data; it was observed that the pseudo-second-order model best represented the relationship. Scanning electron microscopy image and energy dispersive X-ray analysis were also incorporated in support of the study. The result shows that HCAC has the potentiality to remove $\mathrm{Pb}(\mathrm{II})$ from water.
\end{abstract}

Keywords Biosorption - Lead (II) - Heartwood charcoal · Equilibrium study $\cdot$ Kinetic study

\footnotetext{
N. Haloi $(\bowtie) \cdot$ H. P. Sarma

Department of Environmental Science, Gauhati University,

Guwahati 781014, Assam, India

e-mail: nabanita.nita@gmail.com

P. Chakravarty

Department of Chemistry, Birjhora Mahavidyalaya, Bongaigaon,

Assam, India
}

\section{Introduction}

Natural or industrial pollution sources are mainly responsible for heavy metal contamination in different drinking water systems. Metal contamination is a major concern for their harmful effect in the environment. One of the most toxic heavy metals is lead and even in very low concentrations is detrimental to health. Important sources of heavy metal contamination urban industrial aerosols, solid wastes, mining activities, industrial, and agricultural chemicals are responsible for lead entering into the water supply of industrial and consumer utilities. Acid rain breaking down soils and rock, also releases heavy metals into streams, lakes and ground water (Hima et al. 2007). Lead is a cumulative poison and can elicit acute and chronic symptoms of poisoning. It is absorbed into bloodstream as it has high affinity for proteins, which leads to inhibition of the red blood cells. Its organic form is the fat soluble and has a tendency to drain into the brain. Due to the long half life in blood, soft tissues, and bones lead can cause anemia (Raziya et al. 2009; David et al. 2003). For removal of these metals from the environment, adsorption study has gained importance as concerned matter since the beginning of this century by various researchers. Adsorption of heavy metals goes along with a number of extremely important processes of effective significance. The technological, environmental and biological importance of adsorption is enormous because of its practical application (Dabrowski 2001). Several treatment technologies have been developed to remove lead from water and wastewater. Common methods include coagulation (Ogunfowokan et al. 2007), ion exchange, membrane separation, precipitation, electrochemical precipitation, microbiological processes (Valentina 2006), activated carbons, and biosorbents (Raziya et al. 2009). Different 
research studies shows that one of the most effective methods for the treatment of heavy metals from water is adsorption study using low-cost adsorbents. However no report on the utilization of HCAC, for biosorption of lead (II) has been found in literature. Influence of operating conditions like temperature, $\mathrm{pH}$, biosorbent dose, and initial metal concentrations on the biosorption process were investigated in the present study. The equilibrium, kinetics, and thermodynamics of biosorption process were also studied.

\section{Materials and methods}

Charcoal preparation from heartwood

Heartwood of Areca catechu (betel-nut) plant was selected for this study. It was collected from Kamarpara village of Barpeta district (Assam, India). Initially heartwood was separated and washed with double distilled water followed by drying in the sun for 1 week. The material was then carbonized in a muffle furnace at about $100-200{ }^{\circ} \mathrm{C}$ for about $2 \mathrm{~h}$. Finally, the carbon was crushed and sieved $(425 \mu \mathrm{m})$ and stored in desiccators for further analysis.

Preparation of metal ion solution

Metal ion solution was prepared from analytical grade chemical (Merck Ltd). Stock solution of $1,000 \mathrm{mg} / \mathrm{L}$ of $\mathrm{Pb}$ (II) was prepared from $\mathrm{Pb}\left(\mathrm{NO}_{3}\right)_{2}$ in double distilled water. Few drops of $0.1 \mathrm{~N} \mathrm{HNO}_{3}$ were added to prevent precipitation of $\mathrm{Pb}(\mathrm{II})$. The working solutions were prepared from the stock solutions by diluting it to appropriate volumes. The initial $\mathrm{pH}$ of the working solution was adjusted to 5.0 by adding $0.1 \mathrm{~N} \mathrm{HNO}_{3}$ or $0.1 \mathrm{~N} \mathrm{NaOH}$ solutions.

\section{Batch adsorption experiment}

Batch sorption experiments were carried out at room temperature $\left(30 \pm 1{ }^{\circ} \mathrm{C}\right)$. Adsorption experiments were conducted at different conditions viz., contact time (5-35 min), $\mathrm{pH}(2-7)$, initial $\mathrm{Pb}$ (II) ion concentration $(0.5-10 \mathrm{mg} / \mathrm{L})$, and heartwood charcoal of Areca catechu (HCAC) dose $(0.1-0.6 \mathrm{~g})$. The adsorbent dose was maintained at $0.5 \mathrm{~g} /$ $100 \mathrm{ml}$ std. solution. The mixtures were taken in $250 \mathrm{ml}$ conical flask and agitated on a mechanical shaker. The samples were filtered after analysis through whatman 40 filter paper. The concentrations of metals were determined by using atomic absorption spectrophotometer (Perkin Elmer AA 200) with flow injection analyzing mercury hydride generation system (Model FIAS-100) at $283.31 \mathrm{~nm}$ analytical wavelength. Experimental analysis was repeated three times and the results were statistically analyzed. In the present work, adsorption could not be carried out beyond pH 7 due to precipitation of $\mathrm{Pb}(\mathrm{OH})_{2}$ and therefore, the experiment were done in the $\mathrm{pH}$ range of $2-7$.

The amount of adsorbed lead per unit mass of adsorbent $\left(q_{\mathrm{e}}\right)$ was obtained using the following expression:

$q_{\mathrm{e}}=\frac{\left(C_{\mathrm{o}}-C_{\mathrm{e}}\right) V}{m}$

whereas the amount of adsorbed lead per unit mass of adsorbent at time $t\left(q_{\mathrm{t}} \mathrm{mg} / \mathrm{g}\right)$ was obtained by using following expression:

$q_{\mathrm{t}}=\frac{\left(C_{\mathrm{o}}-C_{\mathrm{t}}\right) V}{m}$

where $V$ is the volume of solution treated in liter, $C_{\mathrm{o}}$ is the initial concentration of metal ion in $\mathrm{mg} / \mathrm{L}, C_{\mathrm{e}}$ is the equilibrium metal ion concentration in $\mathrm{mg} / \mathrm{L}, C_{\mathrm{t}}(\mathrm{mg} / \mathrm{L})$ is the concentration of adsorbents at time $t$, and $m$ is the biomass in gram.

\section{SEM and EDX analysis}

The element analysis of HCAC before and after adsorption of $\mathrm{Pb}(\mathrm{II})$ is carried out by the energy dispersive $\mathrm{X}$-ray (EDX) attached on the scanning electron microscopy (SEM, Leo, Model 1430VP) at Central Instrument Facility (CIF) department of Guwahati IIT, Assam.

\section{FT-IR measurements}

FT-IR spectra for both fresh and $\mathrm{Pb}$ (II) treated HCAC were obtained by $\mathrm{KBr}$ pellets methods operated on FT-IR spectrophotometer (Model- Brucker, Vector 22) to investigate the functional groups present in the charcoal and to look into possible $\mathrm{Pb}$ (II) binding sites.

\section{Results and discussion}

\section{Effect of contact time}

Effect of contact time on $\mathrm{Pb}$ (II) biosorption on HCAC is shown in Fig. 1. The absorption rate was fast initially for about 5 min (increase to $85 \%$ ) then later it increased slowly with respect to the contact time increases and finally reaches the equilibrium point at $25 \mathrm{~min}$ (increasing up to $97 \%$ ). Thus equilibrium time was considered to be $25 \mathrm{~min}$, which was considered to be sufficient for the removal of $\mathrm{Pb}$ (II) ions by HCAC. The rate of percentenage of metal removal is higher in the beginning due to a larger surface area of the adsorbent being available for the adsorption of the metals. 


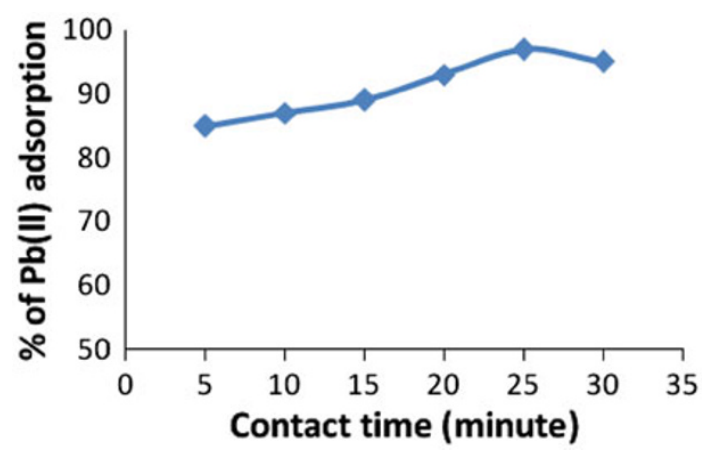

Fig. 1 Effect of contact time on $\mathrm{Pb}$ (II) adsorption on HCAC; $100 \mathrm{ml}$ single metal solution $\mathrm{pH}=5.0$, initial metal ion concentration $\left(C_{\mathrm{o}}\right)=1 \mathrm{mg} / \mathrm{L}$, biosorbent amount $=0.5 \mathrm{~g}$, and temperature $=30^{\circ} \mathrm{C}$

\section{Effect of metal ion concentration}

Effect of different metal solution concentration $(0.1-10 \mathrm{mg} /$ $\mathrm{L}$ ) on the adsorption of $\mathrm{Pb}$ (II) ions by HCAC was shown in Fig. 2, where $0.5 \mathrm{~g}$ adsorbent dose was used. The efficiency of $\mathrm{Pb}(\mathrm{II})$ removal was affected by the initial concentration, with removal percentages decreases corresponding to increased in concentration. These effects may be due to presence of number of exchangeable sites in HCAC structure at low $\mathrm{Pb}(\mathrm{II}) / \mathrm{HCAC}$ ratios. $\mathrm{As} \mathrm{Pb}(\mathrm{II}) / \mathrm{HCAC}$ ratio increases, exchangeable sites are saturated, resulting in a decrease in the adsorption efficiency (Guenay et al. 2007). As due to saturation of biosorption sites at higher concentrations, lower biosorption yield is observed. Therefore dilution of wastewaters containing high metal ion concentrations can increase the purification yield (King et al. 2008).

\section{Effect of amount of adsorbents}

Figure 3 shows that extent of removal of $\mathrm{Pb}$ (II) increases as the amount of adsorbent increases from 0.1 to $0.5 \mathrm{~g}$. The removal efficiency increases up to an optimum dose $(0.5 \mathrm{~g})$, beyond which the increase in removal efficiency is negligible for a given initial concentration. Similar cases are reported in removal of lead (II) using heartwood of A. catechu powder (Chakravarty et al. 2010). According to interpretations of similar data by Srividya and Mohanty (2009), "Higher uptake at low biosorbent concentration could be due to an increased metal to biosorbent ratio, which decreases upon an increase in dry biomass dose."

\section{Effect of $\mathrm{pH}$}

To establish the effect of $\mathrm{pH}$ on the biosorption of lead (II) ion, the batch equilibrium was studied at different $\mathrm{pH}$ values in the range of 2-7 (Fig. 4). The maximum removal of lead (II) ions was observed at $\mathrm{pH} 2-5$ and slightly decreased at higher $\mathrm{pH}$ values. Similarly interpretations of

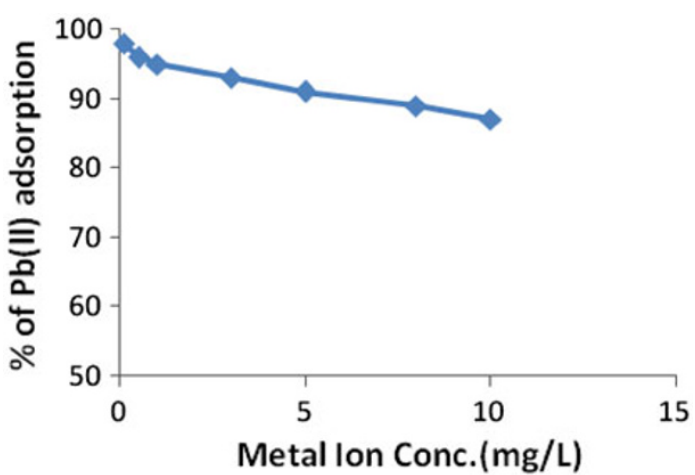

Fig. 2 Effect of $\mathrm{Pb}$ (II) ion concentration on HCAC; initial metal ion concentration $=0.1,0.5,1,3,5,8$, and $10 \mathrm{mg} / \mathrm{L} ; 100 \mathrm{ml}$ of single metal solution; contact time $=25 \mathrm{~min}$; amount of $\mathrm{HPAC}=0.5 \mathrm{~g}$; temperature $=30^{\circ} \mathrm{C}, \mathrm{pH}=5.0$

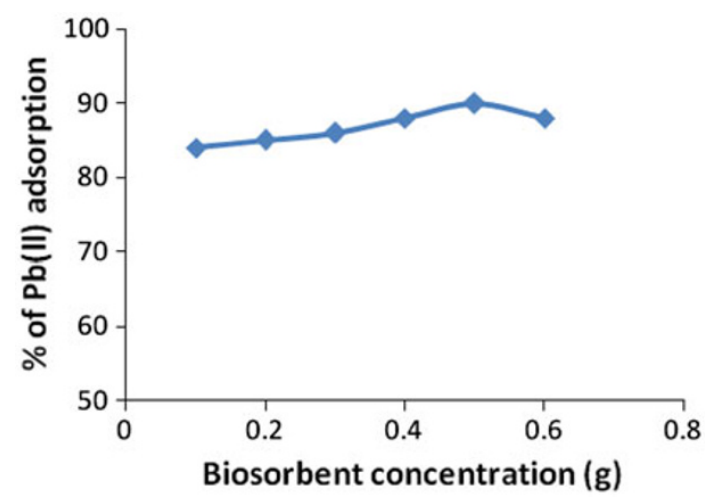

Fig. 3 Effect of biosorbent concentration on $\mathrm{Pb}(\mathrm{II})$ on HCAC; $100 \mathrm{ml}$ of single metal solution; contact time $=25 \mathrm{~min}, \mathrm{pH}=5.0$; initial metal ion concentration $=1 \mathrm{mg} / \mathrm{L}$, temperature $=30^{\circ} \mathrm{C}$

Reddy et al. are cited: "The main factors influencing the $\mathrm{pH}$ on biosorption process were $\mathrm{Pb}$ (II) species and surface functional groups on the adsorbents. It is generally known that at low $\mathrm{pH}$ values, concentration of $\mathrm{H}^{+}$ions far exceeds that of the metal ions and hence $\mathrm{H}^{+}$ions compete with $\mathrm{Pb}$ (II) ions for the surface of the adsorbent which would hinder the $\mathrm{Pb}$ (II) ions from reaching the binding sites of the adsorbent resulting in low adsorption amount of $\mathrm{Pb}(\mathrm{II})$. As the $\mathrm{pH}$ increases, there are fewer protons in the solution and consequently there is lesser competition with $\mathrm{Pb}$ (II) for binding sites. This results in the increase of the biosorption amount of $\mathrm{Pb}$ (II)" (Reddy et al. 2010).

\section{FT-IR analysis}

The FT-IR spectra of fresh and $\mathrm{Pb}(\mathrm{II})$ loaded HCAC shown in Fig. 5 were used to determine the vibrational frequency changes in the functional groups in the adsorbent. The spectra were measured within the range of $400-4,000 \mathrm{~cm}^{-1}$ wave numbers. The spectra were plotted using the same scale on the transmittance axis before and after adsorption. 


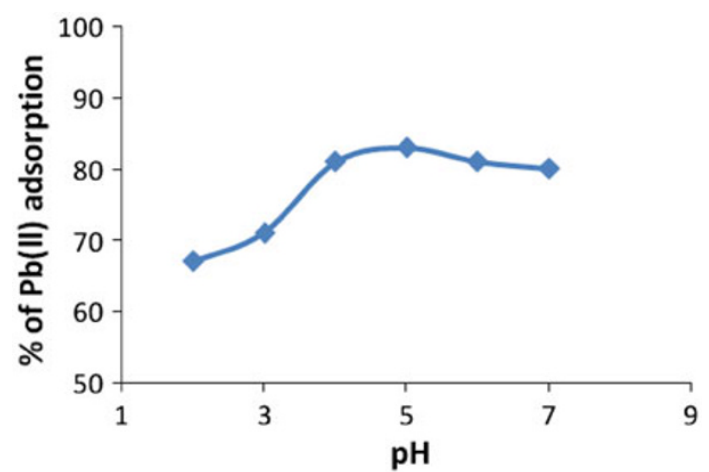

Fig. 4 Effect of $\mathrm{pH}$ on $\mathrm{Pb}(\mathrm{II})$ adsorption on HCAC; $100 \mathrm{ml}$ of single metal solution; contact time $=25 \mathrm{~min}, \mathrm{pH}=2.0,3.0,4.0,5.0,6.0$ and 7.0 ; initial metal ion concentration $=1 \mathrm{mg} / \mathrm{L}$, amount of $\mathrm{HCAC}=0.5 \mathrm{~g}$, Temperature $=30{ }^{\circ} \mathrm{C}$

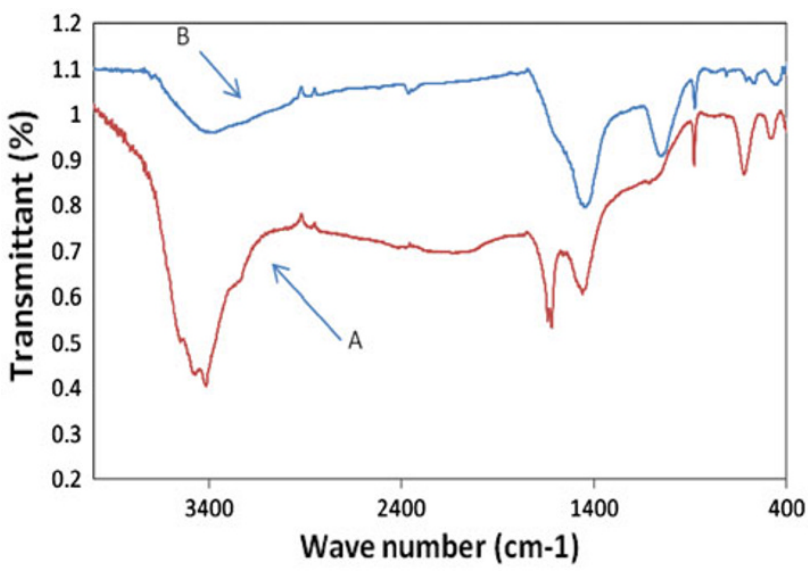

Fig. 5 FT-IR sprectra of fresh HCAC $(A)$ and $\mathrm{Pb}(\mathrm{II})$ loaded HCAC (B)

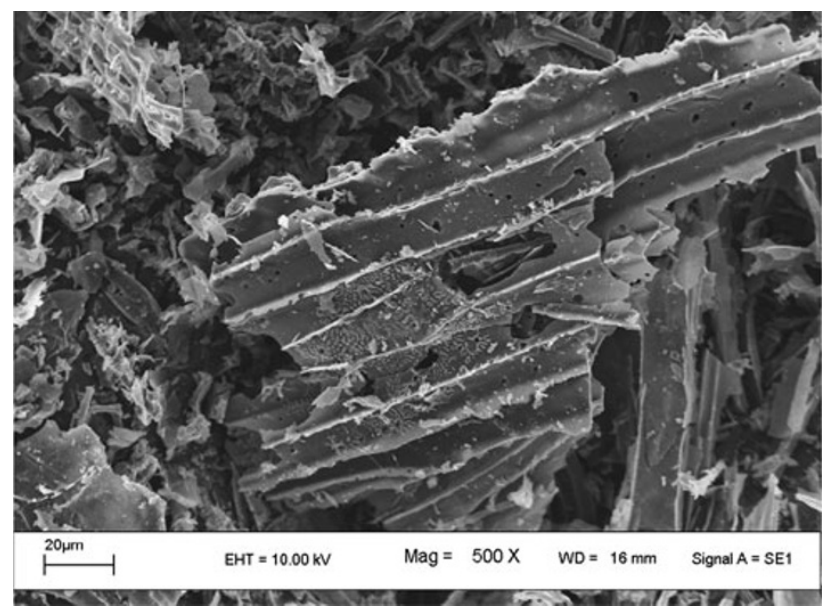

Fig. 6 SEM micrograph of fresh HCAC

The FT-IR spectra of the adsorbent display a number of absorption peaks indicating the complex nature of studied adsorbent as shown in Fig. 5.

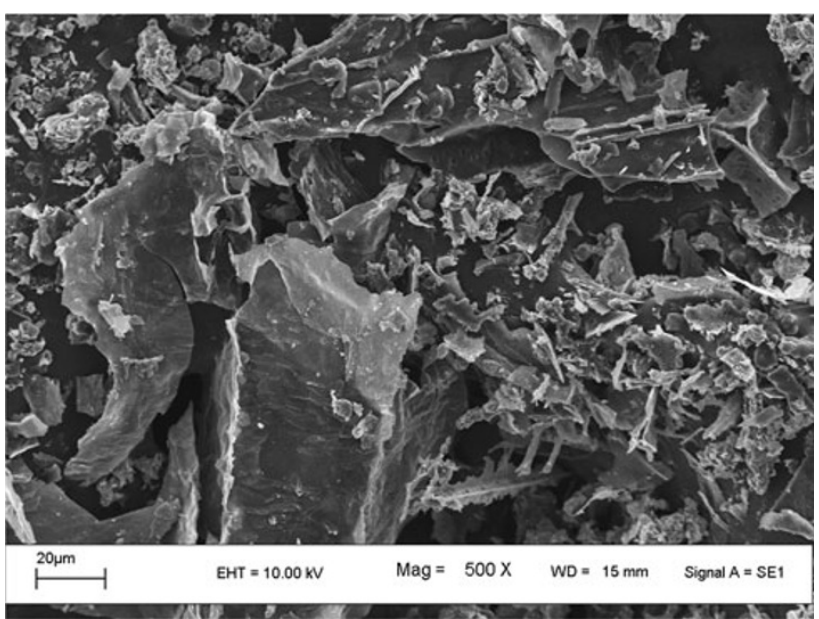

Fig. 7 SEM micrograph of lead(II) loaded HCAC

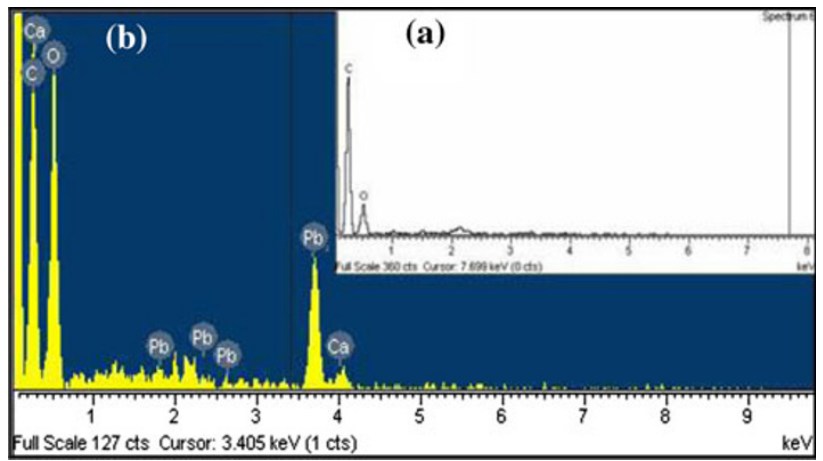

Fig. 8 EDX spectra of a fresh HCAC and b lead(II) loaded HCAC

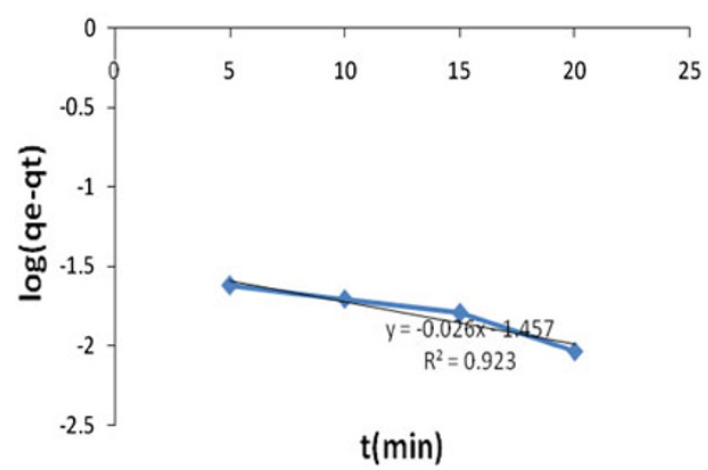

Fig. 9 Pseudo-first-order kinetic plot for the biosorption of $\mathrm{Pb}(\mathrm{II})$ by $\mathrm{HCAC}$ at $30^{\circ} \mathrm{C}$ and $\mathrm{pH} 5.0$

FT-IR spectrum of fresh HCAC shows peaks at $3,400-3,200 \mathrm{~cm}^{-1}$ indicating the presence of $-\mathrm{OH}$ or $-\mathrm{NH}$ groups. A change in peak position $\left(3,359 \mathrm{~cm}^{-1}\right)$ in the spectrum of the $\mathrm{Pb}(\mathrm{II})$ loaded biomass indicates the involvement of these groups in the biosorption of metal ion. The absorption peak at $2,861 \mathrm{~cm}^{-1}$ could be assigned to $-\mathrm{CH}$ stretching vibrations of $-\mathrm{CH}_{3}$ and $-\mathrm{CH}_{2}$ functional 
groups. The absorption peaks at $1,616 \mathrm{~cm}^{-1}$ corresponded to the primary and secondary amide bands. Shifting of these peaks to $1,587 \mathrm{~cm}^{-1}$ in metal loaded spectra, indicated involvement of these groups in metal binding. The peaks at $1,442 \mathrm{~cm}^{-1}$ are attributed to symmetrical bending of $\mathrm{CH}_{2}$ group, asymmetric bending of $\mathrm{CH}_{3}$ and $\mathrm{O}-\mathrm{H}$ bending. Shifting of these peaks to $1,423 \mathrm{~cm}^{-1}$ indicates the participation of these groups in the adsorption process. The additional peaks at 667.32 and $505.31 \mathrm{~cm}^{-1}$ can be assigned to bending modes of aromatic compounds. The shifts in the absorption peaks generally observed indicate the existence of a metal binding process taking place on the surface of HCAC.

Figures 6 and 7 show fresh and lead loaded HCAC micrograph observed under SEM. Lead(II) loaded HCAC is brighter than the fresh one due to $\mathrm{Pb}$ (II) particles adsorbed by HCAC indicating the bisorption process. Analysis of microscopic images provides some interesting new opportunities for future research for establishing the relationship between particle surface textures and cellular responses (Gwynn and Wilson 2001). EDX was also carried out along with SEM, shown in Fig. 8a and b represents fresh HCAC and lead (II) loaded HCAC respectively. From the EDX analysis we can able to get elemental information of the material. A clear picture of lead(II) deposition was observed in Fig. 8a as HCAC was treated with lead(II) where as fresh HCAC has only few elements like $\mathrm{C}$ and $\mathrm{O}$. Figure $8 \mathrm{~b}$ revealed additional chromium signal, which conforms the binding of the metal ion to the surface of the biosorbent.

\section{Kinetic studies}

For analyzing the adsorption kinetics of heavy metal ions, the pseudo-first and pseudo second order kinetic models were applied to experimental data. The first-order rate equation of Lagergrenis represented as:

$\log \left(q_{\mathrm{e}}-q_{\mathrm{t}}\right)=\log q_{\mathrm{e}}-\frac{K_{1} t}{2.303}$

where $q_{\mathrm{e}}$ and $q_{\mathrm{t}}$ are the amount of metal ion sorbed (mg/g) at equilibrium and at time $t$, respectively. $K_{1}$ is the Lagergren rate constant of the biosorbent $(1 / \mathrm{min})$. A plot of $\log \left(q_{\mathrm{e}}-q_{\mathrm{t}}\right)$ versus $t$ gives the result shown in the Fig. 9. The value of $K_{1}$ and $q_{\mathrm{e}}$, calculated from the slope and intercept are presented in Table 1.

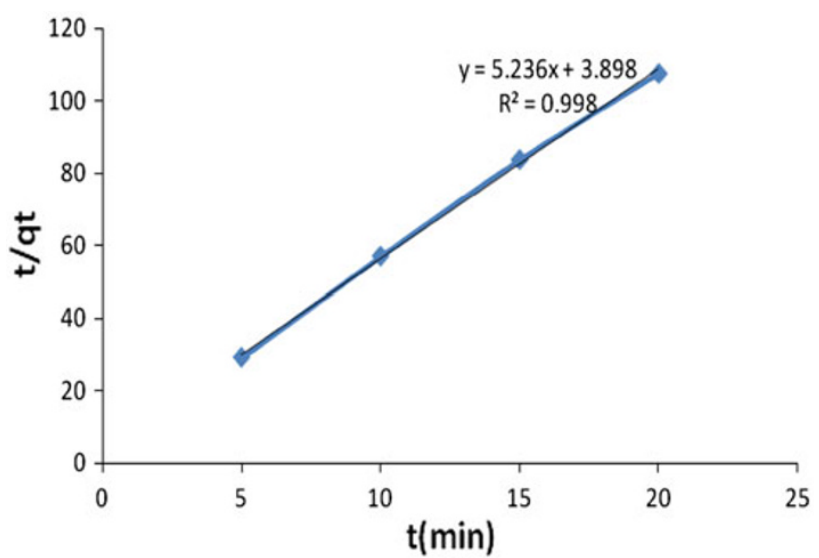

Fig. 10 Pseudo-second order kinetic plot for the biosorption of $\mathrm{Pb}$ (II) by $\mathrm{HCAC}$ at $30^{\circ} \mathrm{C}$ and $\mathrm{pH} 5.0$

The following equation represents pseudo-second-order kinetic model (Lagergren 1898).

$\frac{t}{q t}=\frac{1}{K_{2} q e^{2}}+\frac{1}{q e} t$

where $q_{\mathrm{e}}$ is the equilibrium biosorption capacity and $K_{2}$ (g/ $\mathrm{mg} \min$ ) is the pseudo-second-order rate constant. A plot of $t / q t$ against $t$ gives a linear relationship for the applicability of the second-order kinetic (Fig. 10).

Since the correlation co-efficient $\left(R^{2}\right)$ is 0.998 and the $q_{\text {exp }}$ value is consistent with calculated one, the adsorption system studied could well be explained by pseudo-secondorder kinetic model at all time intervals than the pseudofirst-order kinetic model $\left(R^{2}=0.923\right)$.

Adsorption isotherms

Many sorption isotherm models are usually used to fit the adsorption isotherm data in order to obtain a linear regression data to predict the maximum adsorption capacity of the adsorbent. Langmuir and Freundlich models are the most widely used models in the case of the adsorption of metal ions with bioadsorbents (Fillipovic-Kovacevic et al. 2000).

\section{Langmuir isotherm}

For monolayer adsorption onto a surface containing a finite number of identical sites the Langmuir's isotherm model is valid. The Langmuir treatment is based on the assumption that a maximum adsorption corresponds to a saturated

Table 1 Kinetic model parameters for the biosorption of $\mathrm{Pb}$ (II) by heartwood charcoal of Areca catechu (HCAC)

\begin{tabular}{|c|c|c|c|c|c|c|}
\hline \multicolumn{3}{|c|}{ Pseudo-first-order parameters } & \multicolumn{3}{|c|}{ Pseudo-second-order parameters } & \multirow{2}{*}{$\begin{array}{l}\text { Experimental value } \\
q_{\mathrm{e}}(\mathrm{mg} / \mathrm{g})\end{array}$} \\
\hline$q_{\mathrm{e}}(\mathrm{mg} / \mathrm{g})$ & $K_{1}(1 / \mathrm{min})$ & $R^{2}$ & $q_{\mathrm{e}}(\mathrm{mg} / \mathrm{g})$ & $K_{2}(\mathrm{~g} / \mathrm{mg} \min )$ & $R^{2}$ & \\
\hline 0.0354 & 0.0113 & 0.923 & 0.19099 & 7.027 & 0.998 & 0.19526 \\
\hline
\end{tabular}


monolayer of solute molecules on the adsorbent surface, that the energy of adsorption is constant, and that there is no transmigration of adsorbate in the plane of the surface (Li et al. 2010). It can be expressed as follows:

$q_{\mathrm{e}}=\frac{q_{\mathrm{max}} b C_{\mathrm{eq}}}{1+b C_{\mathrm{eq}}}$

where $q_{\mathrm{e}}$ is the amount of metal ion bound to per gram of the biomass at equilibrium and $C_{\mathrm{e}}$ is the residual (equilibrium) metal ion concentration left in the solution after binding, respectively. $q_{\max }$ is the maximum amount of metal ion per unit weight of sorbent to form a complete monolayer on the surface and $\mathrm{b}$ is the constant related to the affinity of the binding sites. $q_{\max }$ and $b$ can be determined from $C_{\mathrm{e}} / q_{\mathrm{e}}$ versus $C_{\mathrm{e}}$ plot which gives a straight line of slope $1 / q_{\max }$ and intercept $1 / b q_{\max }$ (Aksu 2001).

Favorability of sorption of $\mathrm{Pb}(\mathrm{II})$ on HCAC was tested using the essential feature of the Langmuir isotherm, expressed in terms of a dimensionless constant, $R_{\mathrm{L}}$ (separation factor) which can be calculated as:

$R_{L}=\frac{1}{1+b C o}$

where $b$ is the Langmuir constant and $C_{\mathrm{o}}$ is the initial concentration of metal ion. The value of $R_{\mathrm{L}}$ indicated the type of Langmuir isotherm to be.

$R_{\mathrm{L}}>1$ Unfavorable isotherm

$R_{\mathrm{L}}=1$ Linear isotherm

$R_{\mathrm{L}}=0$ Irreversible isotherm

$0<R_{\mathrm{L}}<1$ Favorable isotherm

The $R_{\mathrm{L}}$ were found to be $0.8116-0.0413$ for concentrations of $0.5-10 \mathrm{mg} / \mathrm{L} \mathrm{Pb}$ (II) in the present work.

The equilibrium data obtained from the adsorption of $\mathrm{Pb}$ (II) onto HCAC were fitted to linear Langmuir equation (Table 2). Linear plot of $C_{\mathrm{e}} / q_{\mathrm{e}}$ versus $C_{\mathrm{e}}$ (Fig. 11) was examined to determine $\mathrm{b}$ and $q_{\max }$ values. The parameter indicates that the HCAC is a suitable $\left(0<R_{\mathrm{L}}<1\right)$ adsorbent for the adsorption of $\mathrm{Pb}(\mathrm{II})$ from aqueous solution.

\section{Freundlich isotherm}

Freundlich isotherm model is useful for multilayer sorption. Freundlich isotherm model for sorption of $\mathrm{Pb}$ (II) on HPAC is presented in Fig. 12. It can be presume from the model that metal ions removal take places on a heterogeneous adsorbent surface (Freundlich 1906).

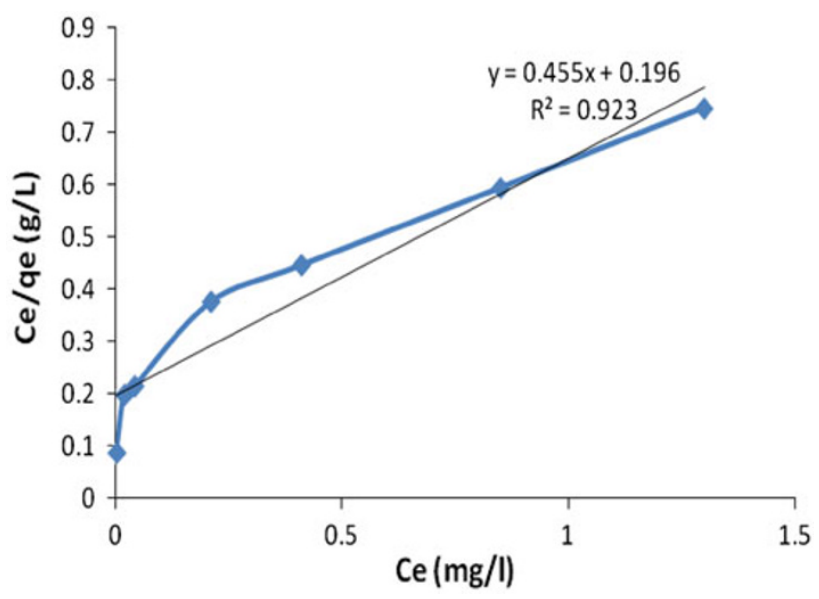

Fig. 11 Langmuir isotherm plot for $\mathrm{Pb}(\mathrm{II})$ adsorption onto HCAC

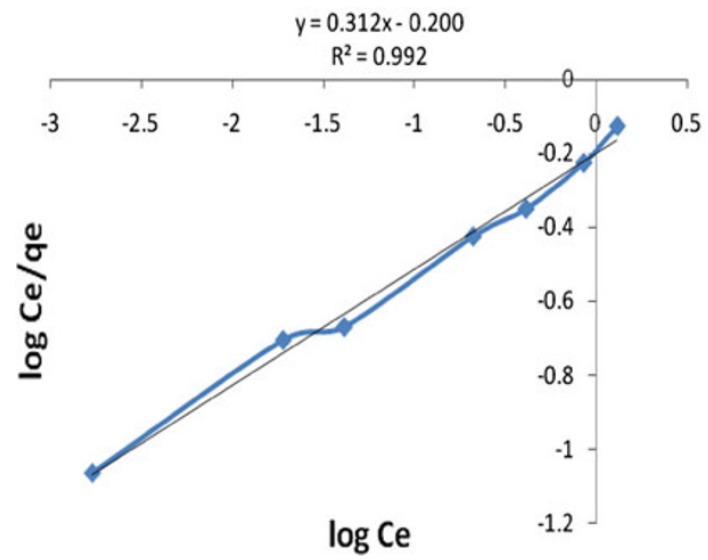

Fig. 12 Freundlich plot for $\mathrm{Pb}(\mathrm{II})$ adsorption onto HCAC

The Freundlich model is empirical in nature and is expressed as.

$q_{\mathrm{e}}=K_{\mathrm{f}} C_{\mathrm{e}}^{1 / n}$

where $\mathrm{C}_{\mathrm{e}}$ is the equilibrium concentration $(\mathrm{mg} / \mathrm{L}), q_{\mathrm{e}}$ is the amount of metal ion bound to per gram of the biomass at equilibrium $(\mathrm{mg} / \mathrm{L})$, and $K_{\mathrm{f}}$ and $\mathrm{n}$ are the Freundlich constants related to the sorption capacity and sorption intensity of the sorbent, respectively. The equation can be linearised in logarithmic form and Freundlich constants can be evaluated by the following equation:

$\log q_{\mathrm{e}}=\log k+\left(\frac{1}{n}\right) \log C_{\mathrm{e}}$

Table 2 Isotherm parameters for $\mathrm{Pb}$ (II) adsorption on heartwood charcoal of Areca catechu (HCAC)

\begin{tabular}{|c|c|c|c|c|c|}
\hline \multicolumn{3}{|c|}{ Langmuir isotherm } & \multicolumn{3}{|c|}{ Freundlich isotherm } \\
\hline$b(\mathrm{~L} / \mathrm{mg})$ & $q_{\max }(\mathrm{mg} / \mathrm{g})$ & $R^{2}$ & $K_{\mathrm{f}}$ & $n$ & $R^{2}$ \\
\hline 2.321 & 2.198 & 0.923 & 0.6309 & 3.205 & 0.992 \\
\hline
\end{tabular}


Table 2 shows isotherm parameters of HCAC. It is found that Freundlich isotherm models fit very well according to the correlation co-efficient values given in the table. Thus, the results of the present study indicate that biosorption of $\mathrm{Pb}(\mathrm{II})$ onto $\mathrm{HCAC}$ is heterogeneous in nature.

\section{Conclusion}

In the present study, $\mathrm{HCAC}$ is established as to be an efficient removal agent of lead (II) from water. About $97 \%$ removals was observed in case of $1 \mathrm{mg} / \mathrm{L}$ metal ion solution at pH 5.0 and at equilibrium time of $25 \mathrm{~min}$. Similar finding are seen in the powdered heartwood of A. catechu experiment (Chakravarty et al. 2010). It is a low cost biadsorbent and available in different parts of the world. The kinetic study shows that pseudo-second order kinetic model is best fitted in the experiment which follows the first order rate equation and also provides a good fitting to the experimental data points. The adsorption isotherm study imply that Freundlich isotherm better explained the experimental data of $\mathrm{Pb}(\mathrm{II})$ biosorption by HCAC than Langmuir with correlation co-efficient 0.992. From the experiment therefore it can be concluded that HCAC can be used effectively as adsorbent for removal of $\mathrm{Pb}$ (II) from waste as well as from domestic water (as it shows very good result in case of very low concentration of $0.1 \mathrm{mg} / \mathrm{l}$ also).

Open Access This article is distributed under the terms of the Creative Commons Attribution License which permits any use, distribution, and reproduction in any medium, provided the original author(s) and the source are credited.

\section{References}

Aksu Z (2001) Equilibrium and kinetic modeling of cadmium (II) biosorption by C.valgaris in a batch system: effect of temperature. Sep Purif Technol 21:285-294
Chakravarty P, Sarma NS, Sarma HP (2010) Removal of lead (II) from aqueous solution using heartwood of Areca catechu powder. Desalination 256:16-21

Dabrowski A (2001) Adsorption from theory to practice. Adv Colloid Interface Sci 93(1-3):135-224

David TW, Myint MT, Sein T (2003) Lead removal from industrial waters by water hyacinth. AU J Technol 6(4):187-192

Fillipovic-Kovacevic Z, Sipos L, Briski F (2000) Biosorption of Cr, $\mathrm{Cu}, \mathrm{Ni}$ and $\mathrm{Zn}$ ions onto fungal pellets of Asperigillus niger 405 from aqueous solutions. Food Technol Biotechnol 38:211-216

Freundlich HMF (1906) Über die adsorption in lösungen. Z Phys Chem 57:385-470

Guenay A, Arslankaya E, Tosun I (2007) Lead removal from aqueous solution by natural and pretreated clinoptilolite: adsorption equilibrium and kinetics. J Hazard Mater 146:362-371

Gwynn I, Wilson C (2001) Characterizing fretting particles by analysis of SEM images. Eur Cell Mater 1:1-11

Hima KA, Srinivasa RR, Vijaya SS, Jayakumar Bondili SV, Venkateshwar S (2007) Biosorption: an eco-friendly alternative for heavy metal removal. Afr J Biotechnol 6(2-5):2924-2931

King P, Anuradha K, Lahari SB, Kumarb YP, Prasad VSRK (2008) Biosorption of zinc from aqueous solution using Azadirachta indica bark: equilibrium and kinetic studies. J Hazard Mater 152:324-329

Lagergren S (1898) Zur theorie der sogenannten adsorption geloster stoffe. K Sven Vetenskapsakad Handl 24:1-39

Li X, Zheng W, Wang D, Yang QY, Cao J, Yue X, Shen T, Zeng G (2010) Removal of $\mathrm{Pb}$ (II) from aqueous solutions by adsorption onto modified areca waste: kinetic and thermodynamic studies. Desalination 258:148-153

Ogunfowokan AO, Durosinmi LM, Oyakunle JAO, Ogunkunle OA, Igbafe LT (2007) Removal of heavy metals from industrial wastewaters using local alum and other conventional coagulants: a comparative study. J Appl Sci 7(10):1416-1421

Raziya N, Tariq MA, Kalsoom A, Ahmad MK (2009) Pb(II) sorption by pyrolysed pongamia pinnata pods carbon (PPPC). Chem Eng J 152:54-63

Reddy DHK, Harinath Y, Seshaiah K, Reddy AVR (2010) Biosorption of $\mathrm{Pb}$ (II) from aqueous solutions using chemically modified Moringa oleifera tree leaves. Chem Eng J 162:626-634

Srividya K, Mohanty K (2009) Biosorption of hexavelant chromium from aqueous solutions by Catla catla scales: equilibrium and kinetics studies. Chem Eng J 155:666-673

Valentina V (2006) Bioremediation of toxic heavy metals using acido thermophilic autotrophies. Bioresour Technol 97:1237-1242 